\title{
Seed collection environment: Effects of forest cover reduction on biometrics and seed lot quality of Bowdichia virgilioides Kunth
}

\section{Ambiente de coleta de sementes: Redução da cobertura florestal na biometria e qualidade de lotes de sementes de Bowdichia virgilioides Kunth}

\author{
Taise Almeida CONCEIÇÃO'; ${ }^{1}$ Andrea Vita Reis MENDONÇA²; Manuela Oliveira de SOUZA ${ }^{3}$ \\ Josival Santos SOUZA ${ }^{4}$; Ricardo Franco Cunha MOREIRA ${ }^{5}$ \\ ${ }^{1}$ Engenheira Florestal, Doutoranda em Genética e Biologia Molecular, Universidade Estadual de Santa Cruz, Departamento \\ de Ciências Biológicas, Rodovia Jorge Amado, Bairro Salobrinho, $45662900 . \quad$ llhéus, BA, Brasil, \\ taise.almeida.conceicao@gmail.com \\ 2 Engenheira Florestal, Doutora em Produção Vegetal, Universidade Federal do Recôncavo da Bahia, andrea@ufrb.edu.br \\ ${ }^{3}$ Autor para correspondência, Bióloga, Doutora em Biotecnologia. Universidade Federal do Recôncavo da Bahia, \\ manuelasouza@ufrb.edu.br \\ ${ }^{4}$ Engenheiro Florestal, Doutor em Biociências e Biotecnologia, Universidade Federal do Recôncavo da Bahia, \\ josival.ufrb@gmail.com \\ ${ }^{5}$ Agrônomo, Doutor em Genética e Melhoramento de Plantas, Universidade Federal do Recôncavo da Bahia, \\ ricardofcm@gmail.com
}

Recebido em: 11-04-2019; Aceito em: 05-05-2019

\begin{abstract}
Considering the growing demand for seed production and seedlings for forest restoration, addressing the implications of landscape changes regarding germination of native species becomes of great value for directing seed collections. The objective of this study is to evaluate the influence of seed collection environment on germination and biometry of fruits and diaspores of Bowdichia virgilioides. Fruits were collected in two forest fragments with distinct characteristics (forest I, open canopy; and forest II, closed canopy), and in isolated trees in pastures. Fruit and seed biometry of the three collection environments was carried out, and a germination test was conducted in a completely randomized design with three treatments (forest I, forest II, and open area) and twenty replicates. Collection site, and therefore changes in forest cover, influences the biometry of fruits and seeds, resulting in lighter seeds and fruits with a smaller size in the fragment with a recent history of disturbance (forest I), as well as the vigor of diaspores of Bowdichia virgilioides. Seeds from forest I expressed a greater vigor, while seeds from the pasture area presented a higher propensity to death and formation of abnormal seedlings. For the production of seedlings and commercialization of seeds for forest restoration, the environment of origin of seeds should be taken into account. It is not recommended to use lots of seedlings from Bowdichia virgilioides seeds from isolated trees, such as those located on pastures and roads.
\end{abstract}

Additional keywords: atlantic forest; germination; landscape fragmentation; seed collection; sucupira.

\section{Resumo}

Considerando a crescente demanda por produção de sementes e mudas visando à restauração florestal, abordar as implicações das alterações da paisagem em aspectos da germinação de espécies nativas torna-se de grande valor para o direcionamento das coletas de sementes. Objetivou-se avaliar a influência do ambiente de coleta de sementes na germinação e a biometria dos frutos e diásporos de Bowdichia virgilioides. Frutos foram coletados em dois fragmentos florestais com características distintas (mata I, dossel aberto, e mata II, dossel fechado) e de árvores isoladas localizadas em pastagem. Realizou-se a biometria dos frutos e das sementes dos três ambientes de coleta e conduziu-se um teste de germinação, em delineamento inteiramente casualizado, com três tratamentos (mata I, mata II e área aberta) e 20 repetições. O local de coleta e, portanto, a alteração na cobertura florestal, influenciam a biometria de frutos e sementes, resultando em sementes e frutos mais leves e de menores dimensões no fragmento com histórico de perturbação recente (mata I), bem como no vigor dos diásporos de Bowdichia virgilioides. As sementes provenientes da mata I expressaram maior vigor, enquanto sementes oriundas de área de pastagem apresentaram maior propensão à morte e à formação de plântulas anormais. Para produção de mudas e comercialização de sementes, visando à restauração florestal, deve-se levar em consideração o ambiente de origem das sementes, sendo recomendado que não ocorra a formação de lotes de sementes de Bowdichia virgilioides provenientes de árvores isoladas, tais como as localizadas em pastagens e estradas.

Palavras-chave adicionais: coleta de sementes; fragmentação da paisagem; germinação; Mata Atlântica; sucupira 


\section{Introduction}

Population growth and the consequent increase in the exploitation of natural resources result in degradation of habitats and fragmentation of ecosystems (Serrote et al., 2016). It is estimated that the forest cover of the Atlantic Forest is currently restricted to about $10 \%$ of the original cover. The fragments are predominantly small and isolated in the midst of highly anthropic landscapes (Silva et al., 2016, Fundação SOS Mata Atlântica \& Instituto Nacional de Pesquisas Espaciais, 2017, MMA, 2017).

This fragmentation has been related to changes in remnants regarding the light regime or temperature, humidity, structure and composition of species, and ecosystemic processes such as pollination and seed predation (Fuchs et al., 2003; Laurance \& Vasconcelos, 2009; Magrach et al., 2011). There is also a decrease in biodiversity (Aguirre \& Dirzo, 2008), especially tropical trees, which are highly vulnerable to forest fragmentation due to complex reproductive systems and low density of individuals (Quesada et al., 2003).

Although it is evident that anthropic changes in the landscape affect the reproduction of plants, there are few studies on the impact of such changes on the quality of seeds of native tropical species. Examples are the studies carried out by Ramos et al. (2007) and Mendonça et al. (2014). The information provided by such studies is of great value as the demand for seeds and seedlings of native species grows concurrently with the urgency of ecological restoration (Costa et al., 2016). Considering the Law no. 12.651/12 (Forest Code), it is estimated that the total area to be restored in Brazil comprises about 21 million hectares (SoaresFilho et al., 2014).

However, one of the main bottlenecks to the use of seeds to restore areas is the place to obtain them in order to restore plant communities (Brancalion et al., 2013, Bucharova et al., 2018). Seed sources may directly affect the prospect of forming viable and self-perpetuating forests (Godefroid et al., 2011). Lower quality seed lots may limit post-seminal germination and development, resulting, for example, in damages to the initial establishment of seedlings. It is essential to consider the context of changes in the landscape to direct seed collection.

Bowdichia virgilioides, known as sucupira, is thus the focus of this study. It is an arboreal species belonging to the Fabaceae family (Albuquerque et al., 2015, Cardoso, 2017) used in forest restoration due to its fast growth and low soil fertility requirement (Lorenzi, 2009). There are no reports in the literature on the influence of the collection environment on the quality of seeds of this species.

$B$. virgilioides is also used for apiarian, landscape and medicinal purposes. It presents a wide distribution in the phytogeographical domains of the Amazon, Caatinga, Cerrado, Atlantic Rainforest, and Pantanal (Cardoso, 2017). Intense extraction, given the quality of the wood (Lorenzi, 2009, Martinelli \& Moraes, 2013), is one of the challenges to its conservation, resulting in its categorization as an endangered species (Martinelli \& Moraes, 2013). In addition, the forest fragmentation scenario into which the species is mainly embedded in both Brazilian biodiversity hotspots (Atlantic Forest and Cerrado) (Mittermeier et al., 2004) echoes the conservation of the remaining populations of $B$. virgilioides.

The objective of this study is thus to evaluate the influence of the collection environment, in the context of forest cover reduction, on germination and biometry of fruits and diaspores of $B$. virgilioides.

\section{Materials and methods}

Fruits of $B$. virgilioides were collected in January 2017 in three areas: forest I, forest II, and an open area. The collection environments are located within the limits of the environmental protection area (EPA) of Joanes-Ipitanga, Fazenda Natal, Simões Filho, Bahia state $\left(12^{\circ} 47^{\prime} 04^{\prime \prime} \mathrm{S}, 38^{\circ} 24^{\prime} 14^{\prime \prime} \mathrm{W}\right.$ ) (Figure 1). The region presents an annual mean temperature of $24-26^{\circ} \mathrm{C}$, and rainfalls of 1,300 to $1,600 \mathrm{~mm}$ (Alvares et al., 2013). The climate in Simões Filho is tropical with a dry summer - As (Alvares et al., 2013), and the average altitude is $52 \mathrm{~m}$.

On January 21, 2017, fruits of the canopy were collected from 15 trees located in three distinct environments: forest I, forest II, and the open area (Table 1). There were five matrices for each environment, spaced at least $100 \mathrm{~m}$ apart. Forest $\mathrm{I}$ is a fragment of the dense ombrophylous forest that has been shallow cut for approximately 30 years. It is characterized by a greater availability of light, with a high frequency of lianas and piassava palm (Attalea sp). Forest II is a fragment of dense ombrophylous forest at an intermediary stage of regeneration with a more closed canopy and, consequently, less light availability in relation to forest I. The open area is characterized as an open field with predominance of grasses and the presence of few isolated arboreal individuals.

For each matrix, five replicates of 100 fruits were measured as for fresh mass and number of healthy seeds (not infested by fungi or insects). A sample of 100 fruits from each matrix was randomly selected to measure the length and width of fruits and the number of seeds per fruit, disregarding those infested by fungi and insects. The seeds of the sample of 100 fruits of each matrix were measured in terms of length, width and thickness using a digital caliper with an accuracy of $0.01 \mathrm{~mm}$, and fresh mass using a precision scale of $0.001 \mathrm{~g}$. The weight of 1,000 seeds (Brasil, 2009) was determined using four samples of 100 seeds per matrix. For each matrix, the seed moisture was determined by the adapted greenhouse method (Brasil, 2009) using two replicates with $1 \mathrm{~g}$ each (about 80 seeds). 


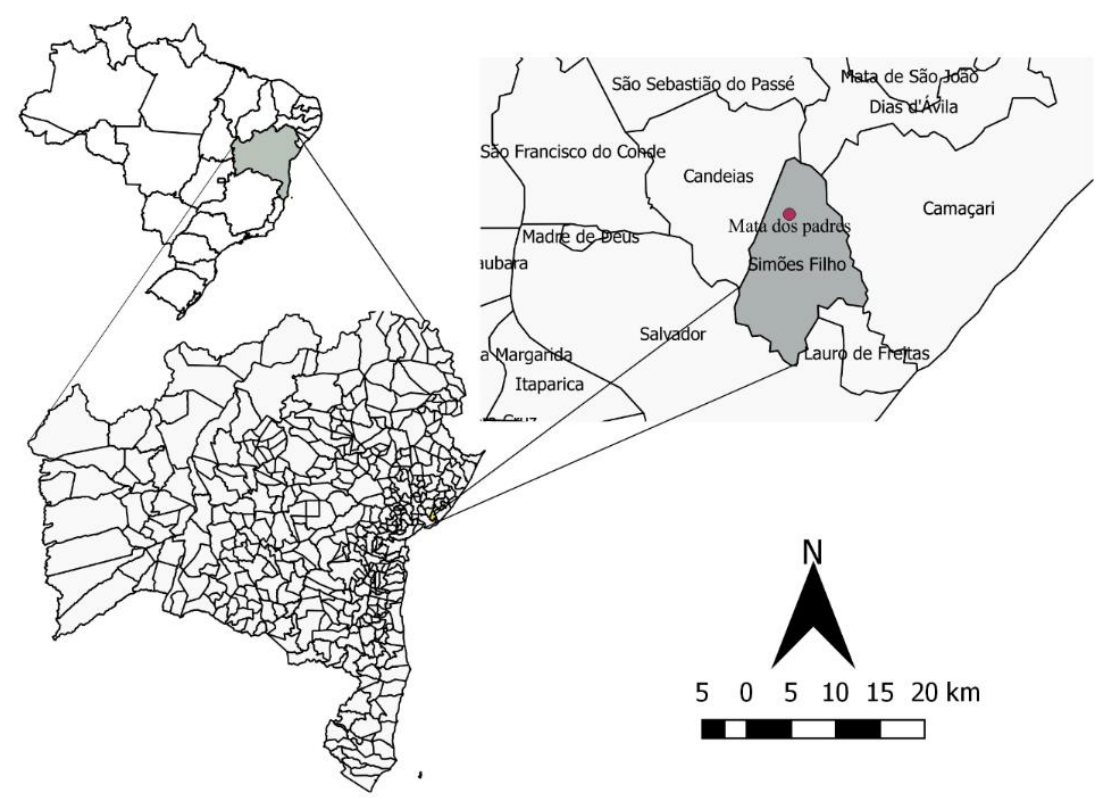

Figure 1 - Study area, fragment of dense ombrophilous forest in the Environmental Protection Area of Lago de Pedra do Cavalo of Joanes-Ipitanga, Simões Filho, Bahia, Brazil.

Germination tests were carried out according to a completely randomized design with three treatments corresponding to the collection environments, and twenty replicates. The replicates consisted of five matrices replicated four times using 25 seeds per replicate. The seeds were submitted to pre-germination, immersion in concentrated sulfuric acid for eight minutes, and subsequent washed under running water.
Afterwards, they were arranged in rolls of germitest paper moistened with distilled water at the proportion of 2.5 times the weight of the paper (Brasil, 2009). The paper rolls were individually placed in clear polyethylene bags and packed in biochemical oxygen demand (BOD) germinators at alternating temperatures of $25-30^{\circ} \mathrm{C}$ and a 12 -hour photoperiod (Albuquerque et al., 2009).

Table 1 - Geographic coordinates and characterization of the trees from seeds of Bowdichia virgilioides Kunth, located in a forest fragment at the Environmental Protection Area of Lago de Pedra do Cavalo Joanes-Ipitanga, Simões Filho-BA.

\begin{tabular}{lcrcrr}
\hline Collection environments & Matrix & $\begin{array}{r}\text { DBH } \\
(\mathrm{cm})\end{array}$ & $\begin{array}{c}\text { Latitude } \\
(\mathrm{utm})\end{array}$ & $\begin{array}{c}\text { Longitude } \\
(\mathrm{utm})\end{array}$ & $\begin{array}{c}\text { Altitude } \\
(\mathrm{m})\end{array}$ \\
\hline Forest I & 16 & 9.4 & 563053 & 8594817 & 107 \\
Forest I & 18 & 11.5 & 563653 & 8595365 & 91 \\
Forest I & 32 & 16.3 & 562538 & 8594338 & 92 \\
Forest I & 54 & 8.6 & 563058 & 8594850 & 111 \\
Forest I & 56 & 29.9 & 562689 & 8594406 & 106 \\
Forest II & 58 & 16.5 & 563125 & 8594260 & 94 \\
Forest II & 59 & 14.2 & 563090 & 8594359 & 71 \\
Forest II & 60 & 19.1 & 563287 & 8594445 & 63 \\
Forest II & 61 & 32.9 & 563342 & 8594394 & 69 \\
Forest II & 62 & 12.2 & 563488 & 8594423 & 77 \\
Open area & 50 & 31.4 & 563002 & 8593713 & 87 \\
Open area & 52 & 31.1 & 562767 & 8593823 & 98 \\
Open area & 64 & 9.8 & 563272 & 8594003 & 58 \\
Open area & 65 & 18.5 & 561784 & 8593697 & 113 \\
Open area & 66 & 23.3 & 561607 & 8593510 & 113 \\
\hline DB & & & & & \\
\hline
\end{tabular}

DBH - Diameter at breast height

The counts were performed daily until stabilization of germination and subsequent formation of normal seedlings. The seed in which there was radicle protrusion was considered as germinated. Seedlings with developed, complete, proportional and healthy shoots and radicles (Brasil, 2009) were counted as normal. The number of germinated seeds, dead seeds, and normal and abnormal seedlings were measured, and the length of shoots and radicle of normal seedlings was measured. The variables evaluated in the 
germination tests were mean time (MT), time intervals between $16 \%$ and $84 \%$ of viable seed germination $\left(\mathrm{U}_{8416}\right)$ (Bewley et al., 2013), average shoot length (SL) and average root length (RL) of normal seedlings considering the initial number of seeds (Guedes et al., 2009), normal seedling formation (\% NSF), and percentage of non-viable seeds-NVS (abnormal seedlings + dead seeds).

The data were analyzed according to their nature so that, in order to evaluate the frequency distribution of fruit and seed dimensions, the number of seeds per fruit and the fresh seed mass in response to the different collection environments (forest I, forest II, and open area), the Chi-Square test ( $\mathrm{R}$ development core team, 2017) was used.

The data resulting from the germination tests, as well as the weight of a thousand seeds (WTS), mass of 100 fruits (MHF), number of healthy seeds in 100 fruits, and seed moisture were also submitted to univariate analysis of variance, and means were compared by Scott Knott test at 5\% using the software R, version 3.1.3 ( $\mathrm{R}$ development core team, 2017). For the univariate analyses of variance, the normality test of Shapiro Wilks residues and Bartlett homoscedasticity test were performed. In the event of not meeting the assumptions, the data transformation was used according to the criteria defined by Sokal \& Rohlf (1995). When the transformation was not sufficient, the Kruskal-Wallis test ( $R$ development core team, 2017) was used.

For the analysis of the variables obtained in germination tests, the analysis of variance was performed using the software $R$, version 3.1.3 ( $R$ development core team, 2017) and the Candisc package (Friendly \& Fox, 2010). To verify homoscedasticity, the Kullback test was used.

\section{Results}

Most fruits of $B$. virgilioides have up to two seeds, corresponding to $80.2 \%$ of the fruits from isolated trees (open area), $70.2 \%$ of forest I, and $69.8 \%$ of forest II (Figure 2). Isolated trees tended to produce more fruits with only one seed $\left(x^{2}=34.89, p\right.$ value $=$ 0.0015).

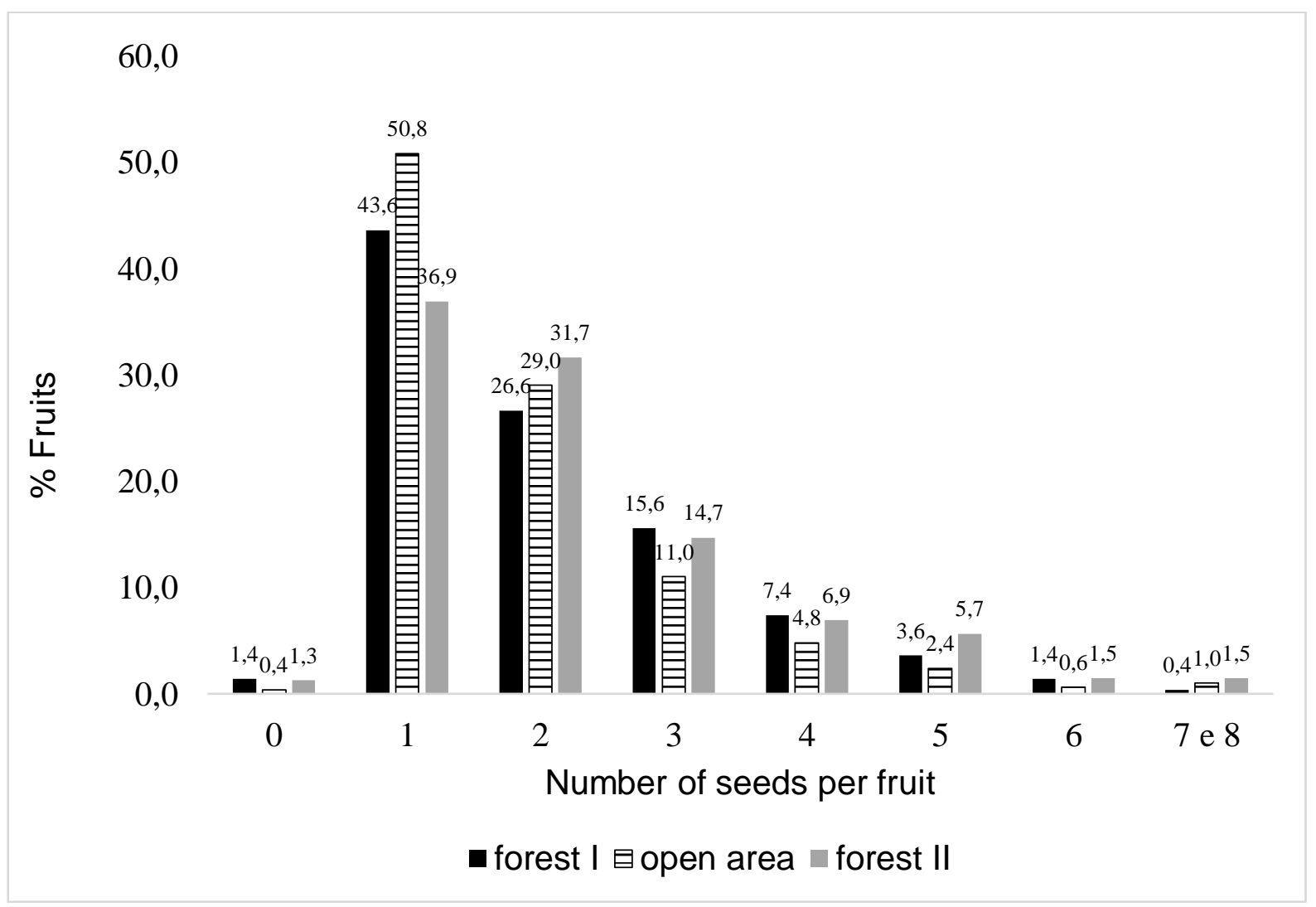

Figure 2 - Fruits'percentage with respect of seed's number per fruit in three environments of Bowdichia virgilioides Kunth, Environmental Protection Area of Lago de Pedra do Cavalo Joanes-Ipitanga, Simões Filho-BA.

The behavior of the distribution of the number of fruits by length classes $\left(X^{2}=66.89\right.$, $\mathrm{p}$ value $=1.25 \times 10^{-9}$ ) and width classes $\left(X^{2}=344.88, p\right.$ value $\left.=2.10 \times 10^{-16}\right)$ was different among collection sites (Table 2). In forest II, there was a greater proportion of fruits with a greater length and width. In the open area, there was a greater proportion of fruits with a greater width. On the other hand, in general, in forest I, a remnant with a history of recent disturbance, fruits of $B$. virgilioides had a smaller length and width in relation to the other environments. 
Table 2 - Number of fruits per class of length $(\mathrm{cm})$ and width $(\mathrm{cm})$ in three collection environments of Bowdichia virgilioides Kunth.

\begin{tabular}{lccccccc}
\hline $\begin{array}{l}\text { Class of } \\
\text { length }(\mathrm{cm})\end{array}$ & Forest I & Forest II & Open area & $\begin{array}{c}\text { Class of width } \\
(\mathrm{cm})\end{array}$ & Forest I & Forest II & Open area \\
\hline$<3.7$ & $101(78)$ & $58(75)$ & $72(78)$ & $<1.0$ & $49(19)$ & $6(18)$ & $9(19)$ \\
3.7 to 4.4 & $105(115)$ & $91(109)$ & $143(115)$ & 1.0 to 1.1 & $102(52)$ & $20(49)$ & $31(52)$ \\
4.4 to 5.1 & $117(120)$ & $109(114)$ & $128(120)$ & 1.1 to 1.3 & $258(179)$ & $108(171)$ & $164(179)$ \\
5.1 to 5.7 & $79(72)$ & $63(69)$ & $72(72)$ & 1.3 to 1.4 & $55(69)$ & $67(66)$ & $81(69)$ \\
5.7 to 6.4 & $57(61)$ & $69(58)$ & $53(61)$ & 1.4 to 1.6 & $43(137)$ & $202(131)$ & $161(137)$ \\
6.4 to 7.1 & $30(33)$ & $49(31)$ & $18(33)$ & $>1.6$ & $2(44)$ & $74(42)$ & $54(44)$ \\
$>7.1$ & $11(20)$ & $38(20)$ & $14(21)$ & & & \\
\hline$X^{2}$ Test $=66.89$ (p value $\left.=1.25^{*} 10^{-9}\right)$ (length), $X^{2}$ Test $=344.88\left(p\right.$ value $\left.=2.2 \times 10^{-16}\right)$ (width). Expected values in paren- \\
theses.
\end{tabular}

The distribution of the number of seeds per length class $\left(x^{2}=429\right.$, $p$ value $\left.=2.2 \times 10^{-16}\right)$, width class $\left(X^{2}=86.42, p\right.$ value $\left.=2.47 \times 10^{-15}\right)$, thickness $\left(x^{2}=353.79, \mathrm{p}\right.$ value $\left.=2 \times 10^{-16}\right)$ and fresh mass $\left(X^{2}=361.3, p\right.$ value $\left.=2 \times 10^{-16}\right)$ differed among collection sites (Table 3). The trees located in forest I present smaller seeds due to a greater proportion of seeds in the smaller classes of length, width and thickness, a pattern that was also observed for fresh seed mass.

Table 3 - Number of seeds per class of length $(\mathrm{mm})$, width $(\mathrm{mm})$, thickness $(\mathrm{mm})$ and fresh mass $(\mathrm{mg})$ in three different collection environments of Bowdichia virgilioides Kunth.

\begin{tabular}{|c|c|c|c|}
\hline Class of length $(\mathrm{mm})$ & Forest I & Forest II & Open area \\
\hline$<3.57$ & $26(20)$ & $18(25)$ & $20(18)$ \\
\hline 3.57 to 3.94 & 76 (53) & 34 (65) & $55(47)$ \\
\hline 3.94 to 4.31 & $177(126)$ & $107(156)$ & $112(114)$ \\
\hline 4.31 to 4.67 & $252(173)$ & $122(214)$ & $170(157)$ \\
\hline 4.67 to 5.04 & $130(162)$ & $202(200)$ & $176(146)$ \\
\hline 5.04 to 5.41 & $36(113)$ & $244(140)$ & $76(102)$ \\
\hline$>5.41$ & $4(53)$ & $138(65)$ & $24(48)$ \\
\hline Class of width $(\mathrm{mm})$ & Forest I & Forest II & Open area \\
\hline$<2.49$ & $39(27)$ & $17(34)$ & $30(25)$ \\
\hline 2.49 to 2.79 & $149(103)$ & $72(127)$ & $102(93)$ \\
\hline 2.79 to 3.08 & $170(214)$ & $294(264)$ & 207 (193) \\
\hline 3.08 to 3.38 & $255(264)$ & $371(326)$ & $202(238)$ \\
\hline$>3.38$ & $88(93)$ & $111(114)$ & $92(84)$ \\
\hline Class of thickness (mm) & Forest I & Forest II & Open area \\
\hline$<1.35$ & $114(72)$ & $64(89)$ & $47(65)$ \\
\hline 1.35 to 1.70 & $350(302)$ & $436(373)$ & $162(273)$ \\
\hline 1.70 to 2.06 & $230(273)$ & $342(336)$ & $283(246)$ \\
\hline$>2.06$ & $7(55)$ & $23(67)$ & $141(49)$ \\
\hline Class of fresh mass $(\mathrm{mg})$ & Forest I & Forest II & Open area \\
\hline$<10.1$ & $22(28)$ & $30(34)$ & $35(25)$ \\
\hline 10.1 to 12.3 & $68(65)$ & $74(80)$ & $61(58)$ \\
\hline 12.3 to 14.4 & $177(106)$ & $85(131)$ & $71(96)$ \\
\hline 14.4 to 16.6 & $213(135)$ & $117(167)$ & $94(122)$ \\
\hline 16.6 to 18.8 & $156(139)$ & $178(172)$ & $103(126)$ \\
\hline 18.8 to 20.9 & 59 (118) & $208(146)$ & 105 (107) \\
\hline$>20.9$ & $4(108)$ & $173(134)$ & $164(98)$ \\
\hline
\end{tabular}


The mass of 100 fruits (MHF) and the number of healthy seeds in 100 fruits (NHS) was higher for the trees located in forest II, while the weight of one thou- sand seeds (WTS) was lower for seeds from forest I (Table 4).

Table 4 - Kruskal-Wallis test for the mass of 100 fruits (MHF), number of healthy seeds in 100 fruits (NHS) and weight of one thousand seeds (WTS) in collection environments of Bowdichia virgilioides Kunth, Environmental Protection Area of Lago de Pedra do Cavalo Joanes-Ipitanga, Simões Filho-BA.

\begin{tabular}{lccc}
\hline Collection environments & MHF & NHS & WTS \\
\hline Forest I & $8.0 \mathrm{~b}$ & $162 \mathrm{~b}$ & $15.4 \mathrm{~b}$ \\
Forest II & $11.7 \mathrm{a}$ & $210 \mathrm{a}$ & $18.8 \mathrm{a}$ \\
Open area & $8.2 \mathrm{~b}$ & $153 \mathrm{~b}$ & $18.8 \mathrm{a}$ \\
\hline Chi -Square & 19.48 & 15.95 & 16.64 \\
p value & $5.9 \times 10^{-5}$ & 0.0003 & 0.0002 \\
\hline
\end{tabular}

Means in the same column followed by the same letter do not differ by Kruskal-Wallis $(p>0.05)$.

According to the multivariate analysis of variance, from the six variables obtained in germination tests (mean time, uniformity, percentage of normal seedling formation, shoot length, root length and percentage of infeasible seeds), the seed collection envi- ronments influenced the quality of diaspores (germination and post-seminal development), as proven by the Pillai, Lambda wilks, Roy and Hotelling-Lawley tests (Table 5).

Table 5 - Significance tests for multivariate analysis of the seed collection locations of Bowdichia virgilioides Kunth, Environmental Protection Area of Lago de Pedra do Cavalo Joanes-Ipitanga, Simões Filho-BA.

\begin{tabular}{lcc}
\hline Tests & Value & Level of significance \\
\hline Pillai & 0.64 & $2.38 \times 10^{-5}$ \\
Lambda wilks & 0.44 & $1.51 \times 10^{-5}$ \\
Roy & 0.81 & $1.23 \times 10^{-5}$ \\
Hotelling-Lawley & 1.05 & $9.76 \times 10^{-6}$ \\
\hline
\end{tabular}

The most responsive variables to seed environment were percentage of non-viable seeds, root

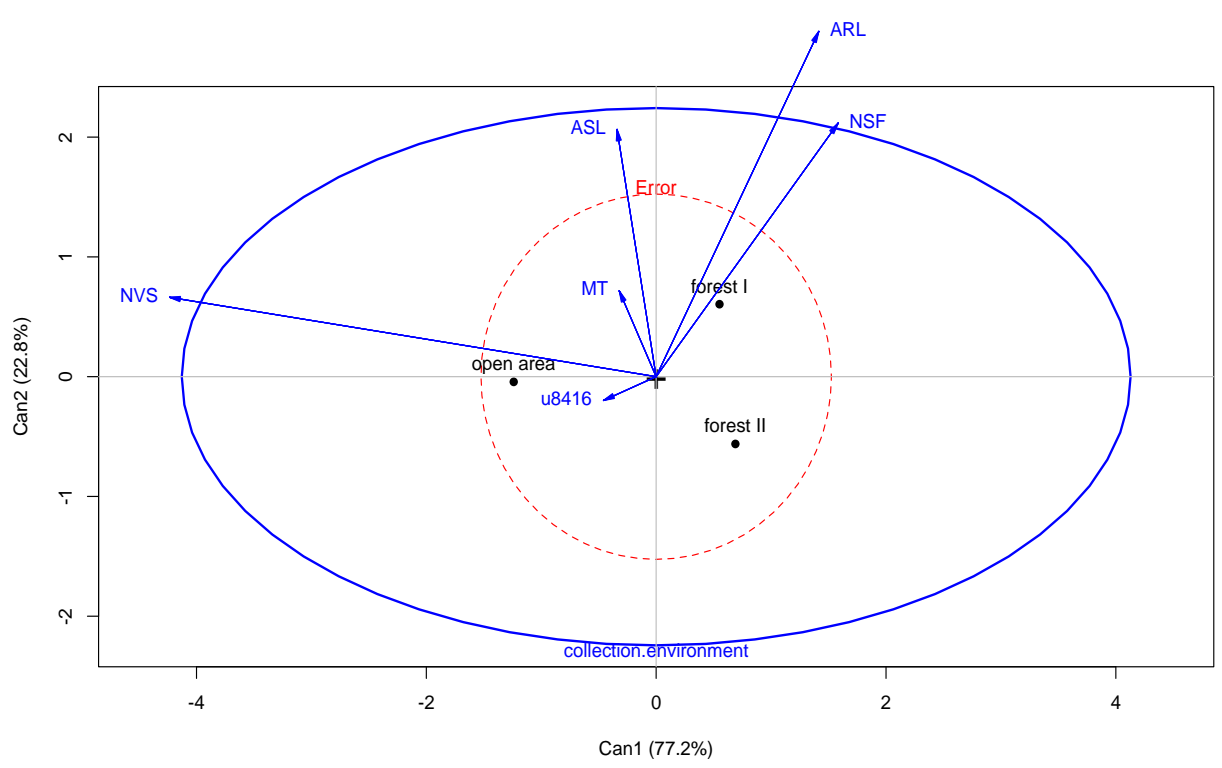

Figure 3 - Graphical dispersion of the scores in relation to the two representative axes of the first two canonical variables (CAN1 and CAN2), related to the six characteristics of the germination test evaluated in the three collection environments: forest I, forest II and open area. 
The mean time and germination uniformity, as well as shoot length of normal seedlings, did not differ between both forest environments and the open area (Table 6). However, seeds collected from trees located in forest $\mathrm{I}$ resulted in a higher formation of normal seedlings (Arc sen $\sqrt{x} / 100$ ) and root length (RL), whereas isolated trees produced seeds with a higher percentage of non-viable seeds ( $\sqrt{ } \% \mathrm{NVS})$. Seeds from forest II presented a lower moisture content at the time of collection (Table 6).

Table 6 - Mean time (MT), uniformity $\left(\bigcup_{8416}\right)$, percentage's normal seedling formation (Arc sen $\left.\sqrt{x} / 100\right)$, shoot length $(S L)$, root length $(R L)$, percentage of non-viable seeds ( $/ N \mathrm{NVS})$ and moisture content $(\mathrm{M} \%)$ of seeds of Bowdichia virgilioides Kunth as a function of the seed collection environments.

\begin{tabular}{lrrcrcrc}
\hline Localização & $\mathrm{MT}$ & $\mathrm{U}_{8416}$ & Arc sen $\sqrt{ } / 100(\mathrm{NSF})$ & \multicolumn{1}{c}{$\mathrm{SL}$} & $\mathrm{RL}$ & $\sqrt{ } \% \mathrm{NVS}$ & $\mathrm{M} \%$ \\
\hline Forest I & $18.7 \mathrm{a}$ & $21.3 \mathrm{a}$ & $69.5 \mathrm{a}(85.6)$ & $10.5 \mathrm{a}$ & $14.2 \mathrm{a}$ & $2.7 \mathrm{~b}(8.2)$ & $9.5 \mathrm{a}$ \\
Forest II & $17.6 \mathrm{a}$ & $21.7 \mathrm{a}$ & $64.0 \mathrm{~b}(77.4)$ & $9.2 \mathrm{a}$ & $12.3 \mathrm{~b}$ & $2.3 \mathrm{~b}(5.4)$ & $8.1 \mathrm{~b}$ \\
Open area & $18.7 \mathrm{a}$ & $23.1 \mathrm{a}$ & $60.5 \mathrm{~b}(74.4)$ & $10.0 \mathrm{a}$ & $11.8 \mathrm{~b}$ & $4.4 \mathrm{a}(19.8)$ & $9.3 \mathrm{a}$ \\
\hline p value & 0.82 & 0.82 & 0.06 & 0.30 & 0.02 & 0.00 & 0.04 \\
CV \% & 34.9 & 51.9 & 18.2 & 26.4 & 22.4 & 37.5 & 9.3 \\
\hline
\end{tabular}

Means in the same column followed by equal letters belong to the same group according to the Scott Knott $(p>0.05)$. No transformed values in parentheses.

\section{Discussion}

The results show that the loss of forest cover may affect seed production, aspects of germination and seedling development, as well as the biometry of fruits and diaspores.

In forest I (a fragment with a recent disturbance history and open canopy), fruits and smaller seeds were proportionally predominant, with a consequent lower weight of 1.000 seeds. In addition, as for the open area (isolated trees), the forest I produced lighter fruits, which is expressed by the fresh mass of 100 fruits, and a lower number of seeds per fruit in relation to forest II (fragment at the middle stage of regeneration and closed canopy).

Greater fresh fruit and seed masses and the number of seeds in 100 fruits resulting from the trees located in forest II may be related to the better edaphic conditions expected for this environment in comparison to other areas under study, which presented loss of forest cover. Soil quality studies have shown that land use and occupation with pastures and cultivated areas result in alterations in physical, chemical and biological characteristics of soils when compared to preserved forest fragments (Jakelaitis et al., 2008), and that the successional stage of forests influence the macrofauna community of the soil (Menezes et al., 2009). Thus, the lower intervention in these attributes in the soil of forest II may have provided a greater nutrition to the matrices located in this condition, affecting fruit development and seed filling, and also helping to understand, in the case of forest II, the largest number of healthy seeds found and the larger dimensions of seeds and fruits and fresh fruit mass.

$B$. virgilioides is a species that has anemocoric dispersion syndrome (Fortunato \& Quirino et al., 2016), and is often classified as a pioneer (Carvalho et al., 2006). The size and mass of fruits may influence dispersion, as well as the mass of seeds and therefore the amount of reserve may have implications in the time that the seed can remain viable in the seed bank. Thus, it is possible that the reduction in forest cover, followed by reduction of fruit size and mass (result found for forest I), results in differentially dispersed fruits, while seeds of forest II, due to the greater mass of seeds, greater viability time in the seed bank, a condition of a forest fragment with a closed canopy, would be advantageous for the species. Such aspects would then have implications on the spatial genetic structure and the temporal recruitment of species and, therefore, deserve to be studied in detail.

Based on germination tests, the better conservation status of forest II and the larger seed sizes did not guarantee the formation of more vigorous seed lots. This was observed for the forest I, in which lots of seeds resulted in higher normal seedling formation, in addition to longer root length.

The greater formation of normal seedlings and root growth from seeds from forest remnants with a shallow cutting history (forest I) may be related to pollination. Bees, mainly of the genus Centris (Silva et al., 2011 ), carry out the pollination of $B$. virgilioides predominantly. There is evidence that species belonging to the genus Centris have a greater reproductive success within native vegetation with a greater light availability (Morato et al., 1999). It is suggested that trees located in forest I receive a greater floral visitation, which contributes to increase cross-pollination when compared to isolated trees and trees located in a forest environment with less light availability (forest II). This fact could provide the species with post-germinative advantages, since an effective pollination, through the quantity and quality of the pollen that reaches the stigma, contributes to the production of good quality seeds (Ashman et al., 2004).

It is suggested, however, that the recruitment of the species in both forest conformations will not be affected since the lower normal seedling formation in forest II seeds, compared to forest I, will be compensated by the higher number of seeds produced in this environment. 
The landscape configuration in pasture areas may be a behavioral barrier for species that perform pollination (Santos-Júnior et al., 2013). For B. virgilioides, a self-compatible species (Silva et al., 2011) in isolated trees, the occurrence of self-pollination increases in detriment to cross-pollination. Consequently, according to Silva et al. (2011), B. virgilioides may present a high rate of inbreeding by passive selfpollination. Cascante et al. (2002), studying the effects of fragmentation on the reproductive biology of Samanea saman (Jacq.) Merr., found that the rate of self-fertilization and the coefficient of inbreeding were higher for isolated trees than for trees in populations of continuous remnants.

On Campomanesia pubescens (DC.) 0. Berg., seeds resulting from self-pollination provided seedlings with a lower development than cross-pollination, and were more susceptible to mortality (Rodrigues et al., 2017). Seeds from isolated matrices located in the open area resulted in a higher number of dead seeds and an increased formation of abnormal seedlings (non-viable seeds). This result reflects a propensity of isolated trees to a greater endogamic depression (Sebben et al., 2000; Santos-Júnior et al., 2013). It results in the loss of vigor due to the increase of deleterious characteristics (Santos et al., 2010).

In fruits from isolated trees, there was also a higher proportion of fruits with only one seed. One of the factors that influences the number of seeds per fruit is the efficiency of the pollination mechanism (Silva \& Pinheiro, 2009), which confirms the lower efficiency of pollination of $B$. virgilioides individuals under drastic conditions of fragmentation, as it happens in the pasture environment.

This result has strong implications for the targeting of seed collections, since harvesting from trees in a drastic reduction of forest cover will compromise germination and post-seminal development, resulting in financial losses to the seedling and seed industry. Other impacts are related to ecological restoration initiatives affecting the production of seedlings in nurseries and the direct seeding in the field, resulting in higher costs, for example, of inputs, infrastructure and logistics. Thus, it is recommended that isolated trees should not be marked as seed collection matrices, although they sometimes appear to be more operative.

\section{Conclusions}

The collection environment, and therefore the reduction in forest cover, influences the dimensions and mass of fruits and seeds, as well as the vigor of the diaspores of $B$. virgilioides. Seeds from the open canopy forest fragment and the greater light availability (forest I) express a greater vigor. For the production of seedlings for forest restoration, it is recommended that seed lots be not obtained from $B$. virgilioides seeds from isolated trees.

\section{Acknowledgements}

The authors would like to thank the Coordination for Improvement of Higher Education Personnel (CAPES) and the Institute of Environment and Water Resources (INEMA) for granting financial support to the research.

\section{References}

Aguirre A, Dirzo, R. (2008) Effects of fragmentation on pollinator abundance and fruit set of an abundant understory palm in a Mexican tropical forest. Biological $\begin{array}{llll}\text { Conservation } & 141 & \text { (2): } & 375-384 .\end{array}$ doi:10.1016/j.biocon.2007.09.014

Albuquerque KS, Guimarães RM, Almeida IF, Clemente ACS (2009) Alterações fisiológicas e bioquímicas durante a embebição de sementes de sucupirapreta (Bowdichia virgilioides Kunth). Revista Brasileira de Sementes 31 (1):12-19. doi: 10.1590/S010131222009000100028

Albuquerque NA, Figueiredo MC, Mendonça EAF, Cinque-Mariano D, Okumura RS, Coletti AJ (2015) Aspectos morfológicos de frutos, sementes e plântulas de sucupira preta. Revista de Ciências Agrárias 58(3):233-239. doi: 10.4322/rca.1720

Alvares CA, Stape JL, Sentelhas PC, Gonçalvez JLM, Sparovek G (2013). Köppen's climate classification map for Brazil. Meteorologische Zeitschrift 22(6): 711728. doi: 10.1127/0941-2948/2013/0507.

Ashman TL, Knight TM, Steets JÁ, Amarasekare P, Burd M, Campbell DR, Dudash MR, Johnston MO, Mazer SJ, Mitchell RJ, Morgan MT, Wilson WG (2004) Pollen limitation of plant reproduction: ecological and evolutionary causes and consequences. Ecology 85(9):2408-2421. doi: 10.1890/03-8024

Bewley JD, Bradford KJ, Hilhorst HWM, Nonogaki H (2013) Seeds: physiology of development germination and dormancy. Springer Science \& Business Media. 392p.

Brasil (2009) Regras para análise de sementes. Ministério da Agricultura, Pesca e Abastecimento, Brasília. 398p.

Bucharova A, Bossdorf O, Hölzel N, Kollmann J, Prasse R, Durka W (2018) Mix and match: regional admixture provenancing strikes a balance among different seed-sourcing strategies for ecological restoration. Conservation Genetics 20 (1): 7-17. doi: 10.1007/s10592-018-1067-6

Cardoso DBOS (2017) Bowdichia in Lista de espécies da Flora do Brasil. Jardim Botânico do Rio de Janeiro. Disponível em <http://floradobrasil.jbrj.gov.br/reflora/floradobrasil/FB2 9489>. Acesso em 16 set. 2017 
Carvalho LR, Silva EAA, Davide AC (2006) Classificação de sementes florestais quanto ao comportamento no armazenamento. Revista Brasileira de Sementes 28(2):15-25.

Cascante A, Quesada M, Lobo JJ (2002) Effects of dry tropical forest fragmentation on the reproductive success and genetic structure of the tree Samanea saman. Conservation Biology 16(1):137-147. doi: 10.1046/j.1523-1739.2002.00317.x

Costa MM (2016) Financiamento para a restauração ecológica no Brasil. In: Silva APM, Marques HR, Sambuichi RHR Mudanças no código florestal brasileiro: desafios para a implementação da nova lei, IPEAInstituto de Pesquisa Econômica Aplicada. p. 235-260.

Fortunato MEM, Quirino ZGM (2016) Efeitos da fragmentação na fenologia reprodutiva de espécies arbóreas presentes em borda e interior de Mata Atlântica Paraibana. Rodriguésia 67(3):

614. doi:10.1590/2175-7860201667305

Friendly M, Fox J (2010) Candisc: Generalized Canonical Discriminant Analysis. $\mathrm{R}$ package version 0.516.

Fuchs EJ, Lobo JA, Quesada M (2003) Effects of forest fragmentation and flowering phenology on the reproductive success and mating patterns of the tropical dry forest tree Pachira quinata. Conservation Biology 17(1):149-157. doi: 10.1046/j.1523-1739.2003.01140.x

Fundação SOS Mata Atlântica, Instituto Nacional de Pesquisas Espaciais (2017) Atlas dos remanescentes florestais da Mata Atlântica período 20152016/relatório técnico. Disponível em http://mapas.sosma.org.br/site_media/download/atlas 20152016_relatorio_tecnico_2017.pdf. (Acesso em 10 nov 2017).

Godefroid S, Piazza C, Rossi G, Buord S, Stevens AD, Aguraiuja R, Johnson I (2011) How successful are plant species reintroductions? Biological Conservation 144 (2):672-682. doi: 10.1016/j.biocon.2010.10.003.

Guedes RS, Alves EU, Gonçalves EP, Viana JS, Medeiros MS, Lima CR (2009) Testes de vigor na avaliação da qualidade fisiológica de sementes Erythrina velutina Willd. (FABACEAE - PAPILIONOIDEAE). Ciência e Agrotecnologia 33 (5):1360-1365. doi: $10.1590 / S 1413-70542009000500023$

Jakelaitis A, Silva AAD, Santos JB, Vivian R (2008) Qualidade da camada superficial de solo sob mata, pastagens e áreas cultivadas. Pesquisa Agropecuária Tropical 38(2):118-127.
Laurance WF, Vasconcelos HL (2009) Consequências ecológicas da fragmentação florestal na Amazônia. Oecologia Brasiliensis 13(3):434-451. doi: 10.4257/oeco.2009.1303.03

Lorenzi H (2009) Árvores brasileiras: manual de identificação e cultivo de plantas arbóreas nativas do Brasil. Instituto Plantarum, Nova Odessa.

Magrach A, Guitia'n J, Larrinaga AR, Guitia NJ (2011) Land-use and edge effects unbalance seed dispersal and predation interactions under habitat fragmentation. Ecological Research 26(4):851-861. doi: 10.1007/s11284-011-0846-Z

Martinelli G, Moraes MA (orgs.) (2013) Livro vermelho da flora do Brasil. Instituto de Pesquisas Jardim Botânico do Rio de Janeiro \& Andrea Jakobson Estúdio. 1100p.

Mendonça AVR, Passos LG, Victor-Junior VV, Freitas TAS, Souza JS (2014) Produção e armazenamento de sementes de Poincianella pyramidalis (Tul.) L. P. Queiroz, em resposta a diferentes ambientes de coleta. Revista Brasileira de Ciências Agrárias 9(3):413-419. doi: 10.5039/agraria.v9i3a2589

Menezes CEG, Fernandes Correia ME, Pereira MG, Batista I, Menezes Rodrigues K D, Couto WH, Anjos L HC, Pinto OI (2009) Macrofauna edáfica em estádios sucessionais de floresta estacional semidecidual e pastagem mista em Pinheiral (RJ). Revista Brasileira de Ciência do Solo 33(6):1647-1656. doi: 10.1590/S0100-06832009000600013

Mittermeier RA, Robles GP, Hoffmann M, Pilgrim J, Brooks T, Mittermeier CG, Lamoreux J, Fonseca GAB (2004) Hotspots revisited: Earth's biologically richest and most endangered terrestrial ecoregions. CEMEX/Agrupación Sierra Madre. 392 p.

Morato EF, Garcia MVB, Campos LAO (1999) Biologia de Centris Fabricius (Hymenoptera, Anthophoridae, Centridini) em matas contínuas e fragmentos na Amazônia Central. Revista Brasileira de Zoologia 16(4):1213-1222. doi: 10.1590/S010181751999000400029

Quesada M, Stoner K, Erosas-Guerrero V, PaláciosGuevara C, Lobo JA (2003) Effects of habitat disruption on the activities of nectarivorous bats (Chiroptera: Phyllostomidae) in a dry tropical forest: implications for the reproductive success of the Neotropical tree Ceiba grandiflora. Oecologia 135(3):400-406. doi: 10.1007/s00442-003-1234-3

R Development Core Team (2017) R: A language and environment for statistical computing. R Foundation for Statistical Computing. Disponível em https://www.Rproject.org/(acesso em: 30-VIII-2017). 
Ramos FN, Jose J, Solferini VN, Santos FAM (2007) Quality of seeds produced by Psychotria tenuinervis (Rubiaceae): distance from anthropogenic and natural edges of atlantic forest fragment. Biochemical Genéticos 45:441-458. doi: 10.1007/s10528-007-90879

Rodrigues SDS, Fidalgo ADO, Barbedo CJ (2017) Reproductive biology and production of seeds and seedlings of Campomanesia pubescens (DC.) $O$. Berg. Journal of Seed Science 39(3):272-279. doi: 10.1590/2317-1545v39n3174807

Santos APM, Romero R, Oliveira PEAM (2010) Biologia reprodutiva de Miconia angelana (Melastomataceae), endêmica da Serra da Canastra, Minas Gerais. Revista Brasileira de Botânica 33(2):333-341. doi: 10.1590/S0100 84042010000200014

Santos-Júnior AD, Tomas WM, Jorge MHA, Hay JDV (2013) Efeito do isolamento de árvores de Sterculia apetala sobre a emergência de plântulas no Pantanal. Biotemas 26(4):61-67. doi: 10.5007/21757925.2013v26n4p61

Sebbenn AM, Kageyama PY, Siqueira ACMDF, Zanatto ACS (2000) Sistema de cruzamento em populações de Cariniana legalis Mart. O. Ktze.: implicações para a conservação e o melhoramento genético. Scientia Forestalis 58: 25-40.
Serrote CML, Reiniger LRS, Stefenon, VM (2016) Simulações em Genética de Populações e Conservação de Recursos Florestais. Paco editorial. 2016. 116p

Silva ALG, Pinheiro MCB (2009) Reproductive success of four species of Eugenia L. (Myrtaceae). Acta Botanica Brasilica 23(2):526-534. doi: 10.1590/S010233062009000200024

Silva ALG, Chaves SC, Brito MJ (2011) Reproductive biology of Bowdichia virgilioides Kunth (Fabaceae) Acta Scientiarum. Biological Science 33(4):463-470. doi: 10.4025/actascibiolsci.v33i4.9003

Silva JMC, Pinto LP, Hirota M, Bedê L, Tabarelli M (2016) Conservação da Mata Atlântica brasileira: um balanço dos últimos dez anos. In: Cabral DC, Bustamante AG Metamorfoses florestais: Culturas, ecologias e as transformações históricas da Mata Atlântica. Editora Prismas (eds.) Curitiba, p.435-458.

Soares-Filho $B$, Rajão $R$, Macedo $M$, Carneiro $A$, Costa W, Coe M, Alencar A (2014) Cracking Brazil's forest code. Science 344(6182): 363-364

Sokal RR, Rohlf FJ (1995) Biometry: The Principles and Practice of Statistics in Biological Research. 3 ed. New York.880p. 